of their movements available, householders could render greater assistance than by isolated and spasmodic attempts at destruction. Pig keepers and poultry keepers contributed to the discussion by giving their experiences of livestock management in built-up areas, and suggested standards that might be laid down to protect public health and amenities after the War. It was agreed that while a measure of livestock keeping is necessary to maintain soil fertility, the disposal of small amounts of manure presents a difficult problem. Some pig clubs have got over the difficulty by composting. The subjects of food storage and insect pests associated with the different classes of livestock were referred to. The chairman, Mr. John Green, said that at law livestock keeping is permitted anywhere provided it does not amount to a nuisance, but that following a number of cases at the end of the last century, many public authorities had passed by-laws under the Public Health Acts, restricting these enterprises.

\section{Phenology of 1942}

WITH admirable promptitude in these difficult times, the fifty-second annual phenological report of the Royal Meteorological Society has been issued, covering the observations on the weather and fauna and flora in Britain from December 1941 to November 1942. This is interesting because the cold spring included the coldest February in England and Wales since 1895 , and the dry period in summer included a thirty-two days drought, the longest for thirteen years. It was an abundant year for crops and wild and cultivated fruits of almost every kind, while grass fields appeared exceptionally green in the autumn and the season was sufficiently free from frosts to produce a wealth of autumn tints, many oaks keeping their foliage in sheltered places into December. Migrant birds were uniformly late in reaching the most northerly zone in spring, but the cuckoo was the only bird to be late in all three zones, the other zones showing first migrant arrivals in advance of the average dates. 1942 was a year of comparative scarcity of immigrant Lepidoptera, especially of the painted lady butterfly, although some localities had considerable arrivals, and three migrant insects, the red admiral butterfly and the silver $\mathrm{Y}$ and convolvulus hawk moths, were recorded in the Shetlands.

Two hundred and sixty-four observers sent in their records, a slight reduction on previous years. It is noted that in order to arrive at a high degree of accuracy in average values for plant and insect dates, there should be revisions at intervals of five or ten years ; also that weather responses in different districts must be analysed separately when the meteorological characteristics of the season differ in those districts. Responses depend on the incidence of the weather in relation to the average dates, so that they are not necessarily uniform. The zone diagrams show that there is less difference in date between groups, as a whole, in different zones, than there is between the dates from observing stations in individual groups : the former may amount to a few days but the latter to a few weeks.

\section{Gifts to Universities of Leeds and Sheffield}

A FEW weeks ago, it was announced that $\mathrm{Mr}$. Henry Ellison had given the University of Leeds $£ 50,000$ to create an endowment fund for the provision of post-graduate fellowships for research in pure and applied chemistry and physics (see NATURE, March 13, p. 303). He has now put the scientific world further in his debt by a gift of $£ 25,000$, spread over seven years, to the University of Sheffield, with the suggestion that the money be expended during the years immediately following the War on a scientific research fellowship. Mr. Ellison, who is chairman of the Yorkshire Tar Distillers, Ltd., and has been associated for many years with the Sheffield Chemical Company and the Mirvale Chemical Company, is an old student of the Yorkshire College, the forerunner of the University of Leeds. His gifts, besides being of direct service to the industries in which he is himself directly interested, form a notable addition to the resources available in Great Britain for scientific research.

\section{Co-operative Systems in European Agriculture}

ThE British Association, through its Division for the Social and International Relations of Science, is arranging a conference on "Co-operative Systems in European Agriculture", to be held on Friday and Saturday, April 16 and 17, at the Royal Institute of International Affairs, Chatham House, St. James's Square, S.W.1, by kind permission of the Institute. The Conference will be opened by Sir Richard Gregory, president of the Association, and there will be four sessions, the subjects of which will be cooperation in three groups of European countries (north, west and east), and immediate relief after the War. Tickets of admission will be obtainable from the British Association, Burlington House, London, W.1.

\section{Announcements}

Sir Harold Hartuey has been appointed general treasurer of the British Association as from April 1, the beginning of a new financial year. He succeeds Prof. P. G. H. Boswell, who has resigned after twelve years service in office, first as a general secretary (1931-35), and then as general treasurer (1935-43). The gratitude due from the Association to Prof. Boswell has been acknowledged in a resolution by the General Committee.

At the annual general meeting of the Institution of Chemical Engineers, on April 2, the following medals for 1942 were presented : Osborne Reynolds Medal, Mr. L. O. Newton; Moulton Medal, Mr. W. K. Hutchison and Dr. E. Spivey, for their paper on "Design and Performance of Cooling Towers"; Junior Moulton Medal and Auard, Dr. S. H. Wade, for his paper on "Evaporation of Liquids in Currents of Air"; William Macnab Medals, Mr.J.H. Sharp and Mr. F. J. Wilkins.

The Committee on Africa, the War and Peace Aims has issued as a supplement to "The Atlantic Charter and Africa from an American Standpoint" a compilation by Rev. Dr. E. W. Smith entitled "Events in African History". This is a chronology in two parts, ancient and modern, with an index mainly of references to persons, places and organizations, with some subject entries. The modern chronology which occupies the greater part of the brochure is in three sections covering, respectively, the period of unrestricted slave-trade, 14151807 ; the period of struggle to extirpate slave-trade and slavery; exploration; partition; preliminary economic development; and expansion of Christianity (1807-1918); and the period of trusteeship (1919-1942). 